\title{
Locating the epidural space in obstetric patients-ultrasound a useful tool: Continuing Professional Development
}

\author{
Mrinalini Balki, MD
}

Received: 1 July 2010/Accepted: 21 September 2010/Published online: 11 November 2010

(C) Canadian Anesthesiologists' Society 2010

\begin{abstract}
Purpose The objective of this continuing professional development module is to describe the role of ultrasound for spine demarcation before placement of neuraxial blocks and to provide a comprehensive systematic approach towards ultrasound scanning in obstetric patients.

Principal findings Ultrasound imaging of the lumbar spine has been shown to be effective in improving the success rate of neuraxial blocks in obstetric patients. The success rate of ultrasound-guided epidural insertions at first attempt was found to be 30-60\% greater when compared with the traditional epidural method. Pre-puncture ultrasound scanning can provide reliable and accurate information on several critical aspects needed for successful epidural placement, such as the interspace level, the midline of the spine, the optimal puncture point, the optimal angle for needle insertion, and the depth to the epidural space. Ultrasound scanning of the lumbar spine can generate images in two distinct patterns - one in the transverse plane represented by a "flying bat" and the other in the paramedian longitudinal plane represented by a "saw-tooth" configuration. Both approaches allow the visualization of the ligamentum flavum and the dura mater in addition to other adjacent bony landmarks. A stepwise scanning approach can serve as a useful guide to facilitate
\end{abstract}

Electronic supplementary material The online version of this article (doi:10.1007/s12630-010-9397-y) contains supplementary material, which is available to authorized users.

\section{Balki, MD (ه)}

Department of Anesthesia and Pain Management, Mount Sinai

Hospital, University of Toronto, University Avenue, Room

1514, Toronto, ON M5G 1X5, Canada

e-mail: mrinalini.balki@uhn.on.ca the successful placement of epidural needles in patients with both normal and abnormal spinal anatomy.

Conclusions Incorporating the use of lumbar spine ultrasound scanning into day-to-day clinical practice may improve the ease of performing epidurals as well as add to patient safety and comfort.

\section{Objectives of this Continuing Professional Development (CPD) module}

After reading this module, the reader should be able to:

1. Understand the principles of ultrasound imaging and the interpretation of sonoanatomy of the lumbar spine in obstetric patients;

2. Identify normal ultrasound image patterns in various scanning planes and determine their applications in facilitating spinal and epidural techniques;

3. Recognize sonoanatomy patterns in patients with spine abnormalities and morbid obesity; and

4. Discuss the potential impact of the ultrasound-guided technique in improving the quality and safety of neuraxial blocks.

Ultrasound has several applications in the practice of medicine. In anesthesia, this technology has been associated with substantial benefits in the placement of peripheral nerve blocks and central venous cannulations; likewise, its routine use in clinical practice for guiding neuraxial blocks can greatly improve their precision and effectiveness. In 2008, the National Institute for Health and Clinical Excellence (NICE) in the United Kingdom already issued guidance regarding the use of ultrasound for placement of epidural catheters. ${ }^{1}$ 
The traditional method to perform neuraxial blocks involves a "blind" approach based only on anatomical landmarks. However, these landmarks may not always be evident or even accurate. This situation becomes even more complex and the technique more tentative when the anatomical landmarks are difficult to palpate due to obesity and/or spine abnormalities. This twofold problem-a blind approach and variable patient anatomy-may account for many of the complications that arise during neuraxial block insertions. Such complications include multiple puncture attempts, difficult placement, trauma to various vital structures, and unintentional dural puncture. Ultrasound technology available today has the potential to add to the safety and efficiency of performing neuraxial blocks by "un-blinding" the target and providing crucial information on the structure of the spine in different planes.

However, the successful and safe use of ultrasound depends on the appropriate understanding of its basic concepts and an accurate interpretation of ultrasound images based on relevant anatomy. The purpose of this module is to provide guidance on the systematic assessment of the lumbar spine using ultrasound and to illustrate an evidence-based approach for its use.

\section{Basic concepts of spinal ultrasound}

The first step in the systematic lumbar scanning process is to select an appropriate transducer to obtain the best possible image. A high frequency (7-15 MHz) linear transducer is preferred for peripheral nerve blocks and central venous cannulations where the structures to be visualized are located superficially. This transducer produces a high-resolution image; however, it has poor beam penetration. Since the spinal structures are located deeper, a transducer with deep penetration of sound waves is appropriate for lumbar ultrasound. This can be achieved by a low frequency $(2-5 \mathrm{MHz}$ or $3-6 \mathrm{MHz}$ ) curved array transducer, although one of its limitations is image resolution. ${ }^{2}$ The curved surface of the transducer provides a wide footprint of the image, which allows the visualization of anatomical structures that are located more laterally, such as the transverse processes. It is recommended that depth settings of 9-14 cm be utilized in order to view all of the relevant structures with optimal resolution. The ultrasound beam is only $1 \mathrm{~mm}$ thick and passes through the centre of the transducer; therefore, an angle of its incidence perpendicular to the structures of interest is likely to provide the optimum quality image. The $90^{\circ}$ angle is most appropriate because the ultrasound waves are reflected back from the structures and returned to the transducer to the maximum extent at this angle.
Spinal ultrasound is particularly challenging because the structures of interest for neuraxial blocks are not only deep but they are also shielded by a complex bony vertebral cage. The ultrasound waves do not pass through bone because of its high acoustic impedance, and this hindrance impedes visualization of deeper structures. Bone appears intensely hyperechoic (bright) on the ultrasound image and produces a hypoechoic (dark) shadow underneath, termed an "acoustic shadow". Hence, while scanning through bony structures, it is necessary to find an "acoustic window", which is a gap between bony areas through which ultrasound waves can be transmitted to visualize the deeper structures. $^{3}$ Two such acoustic windows can be obtained while performing lumbar ultrasound scanning-one through a transverse or axial plane in the interspinous space and another through a paramedian longitudinal or sagittal plane in the interlaminar space. ${ }^{4,5}$

\section{Sonographic assessment of the lumbar spine}

Lumbar spine ultrasound scanning can be done either as a "pre-puncture" procedure to demarcate the landmarks or as "real-time" scanning to provide dynamic images during epidural placement. Currently, the "pre-puncture" method is preferred, as it is simple and easy to perform and provides reliable information. ${ }^{6}$ It is important to ensure that the scanning is performed in the same patient position as for the epidural needle placement. The following information can be obtained during pre-puncture ultrasound scanning: 1) the interspace level; 2) the midline of the spine; 3) the puncture point; 4) the angle for needle insertion; and 5) the depth to the epidural space.

Paramedian longitudinal or sagittal plane scanning

The preferred scanning plane for counting the interspace levels through interlaminar windows is obtained by placing the transducer longitudinally along the spine, parallel to it, $2-3 \mathrm{~cm}$ lateral to the midline, and directing it towards the centre of the spinal canal. With this paramedian longitudinal or sagittal plane scanning, multiple levels can be visualized in one scanned image. The sonoanatomical structures that can be seen in this plane include 1) sacrum, 2) lamina, 3) ligamentum flavum and dorsal dura mater, which typically appear as a single "ligamentum flavumdura" (LF-D) unit, and 4) ventral dura (VD) mater, posterior longitudinal ligament (PLL) and vertebral body (VB), which appear as another single VD-PLL-VB complex (Fig. 1, Video 1). The individual components of LF-D unit and VD-PLL-VB complex cannot be differentiated from each other with the ultrasound machines currently available. 


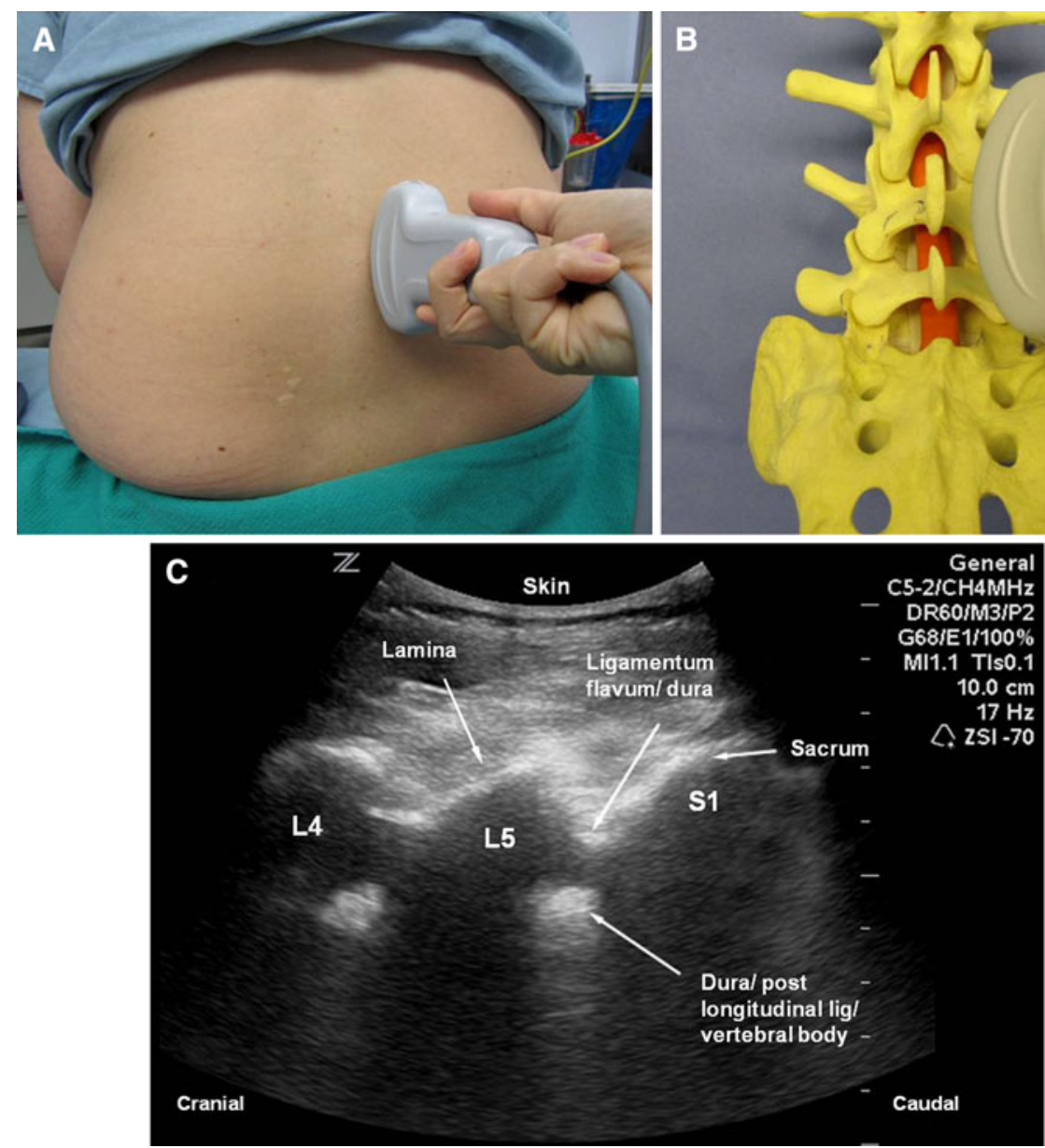

Fig. 1 (A) Scanning in the paramedian longitudinal plane; (B) Probe oriented parallel to the axis of spine model; (C) Ultrasound image with a typical saw-tooth sign: hyperechoic flat band on the right represents sacrum, saw-teeth indicate lamina, and the two parallel bands between saw-teeth correspond to the interspace containing the ligamentum flavum-dorsal dura unit (upper) and the ventral duraposterior longitudinal ligament-vertebral body complex (lower)

While scanning in this plane, the ultrasound transducer is moved cephalad using the sacral level as a starting point. The upper border of the sacrum can be identified as a hyperechoic flat reflective surface on the ultrasound image at about $3-5 \mathrm{~cm}$ under the skin. As the transducer is advanced cephalad, the interspace can be identified as an indentation of the reflective surface. This image is then followed by a "saw-tooth" pattern wherein the teeth of the saw represent the lamina interrupted by interspaces (Fig. 2, Video 2). Each interspace consists of two parallel hyperechoic bands or an "=" (equal) sign, with the LF-D unit as the outer band and the VD-PLL-VB complex as the deeper one. The desired interspinous level can be identified by counting the alternating laminae and the corresponding interspaces. The midpoint of the interspace can also be
Fig. 1 (A) Balayage dans le plan longitudinal paramédian; (B) Sonde orientée parallèlement à l'axe du modèle de la colonne; (C) Image échographique avec un signe typique en dents de scie: la bande plate hyperéchogène sur la droite représente le sacrum, les dents de scie indiquent les lames vertébrales (lamina), et les deux bandes parallèles entre les dents de scie correspondent à l'interespace contenant l'unité ligament jaune - dure-mère dorsale (ligamentum flavum/dura, en haut) et le complexe dure-mère ventrale - ligament longitudinal postérieur corps vertébral (dura/post longitudinal lig/vertebral body, en bas)

determined by centring a particular interspace on the screen.

\section{Transverse or axial plane scanning}

Once the level to be scanned is identified in the paramedian longitudinal plane, the transducer is turned perpendicular to the axis of the spine at the chosen level to obtain a view of the entire interspace. The structures that can be visualized in this plane include (1) LF-D unit, (2) VD-PLL-VB complex, (3) articular processes, and (4) transverse processes (Fig. 3, Video 3).

The LF-D unit and the VD-PLL-VB complex can be visualized as midline structures, which also produce a hyperechoic "=" sign in the middle of the interspace. The 

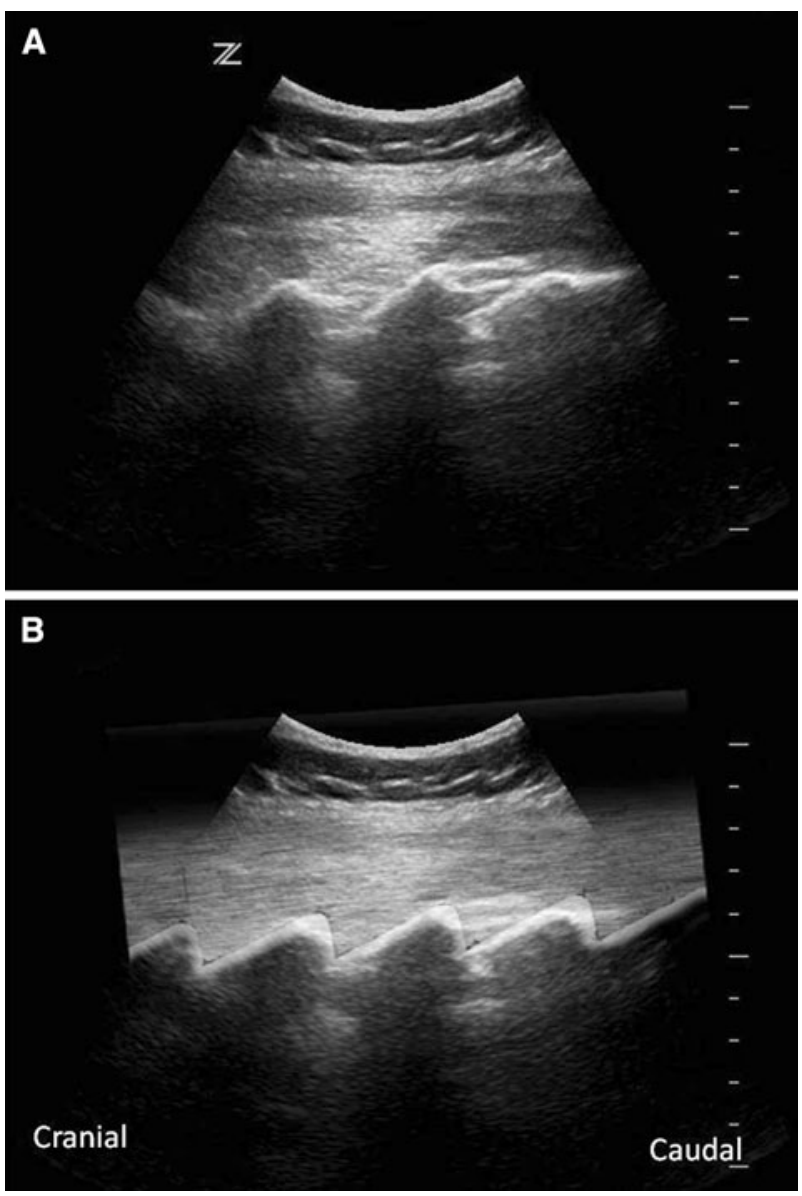

Fig. 2 (A) Ultrasound image showing multiple lumbar interspaces in the paramedian longitudinal plane; (B) Artist's rendition indicating a saw-tooth pattern

Fig. 2 (A) Image échographique montrant des espaces interépineux lombaires multiples dans le plan longitudinal paramédian; (B) rendu artistique indiquant un tracé en dents de scie

articular processes and transverse processes appear as the bilateral symmetric hyperechoic structures. The transverse processes appear as the lateral elongations of the LF-D unit reflections. The typical view in the transverse plane has been described as resembling a "flying bat" ${ }^{\text {(Fig. 4). As }}$ the transducer is moved cephalad or caudad to the interspace, the upper or lower spinous process can be visualized. Hence, the midline of the spine can be identified as corresponding to the spinous process, which produces a hyperechoic signal below the skin with a hypoechoic triangular shadow underneath (Fig. 5). Thus, scanning in this plane can determine both the midline of the spine and the middle of the interspace.

\section{Clinical information from lumbar ultrasound scanning}

Once the best image of the interspace structures or the "=" sign is captured in the transverse or the paramedian longitudinal plane, it is centred on the screen and the image is frozen. With the transducer kept still, the skin is marked at the centre of both the upper and the lateral aspects of the transducer. The transducer is then removed, and lines are drawn to connect these marks. The insertion point is determined by the intersection of these two lines (Fig. 6). In this manner, the insertion point for both the midline and the paramedian punctures can be determined by scanning in the transverse and the paramedian longitudinal planes, respectively. Since midline punctures are commonly performed in the obstetric population, a transverse approach is preferred to determine the insertion point.

In addition to marking the insertion point, the angle of the transducer providing the best image of the interspace structures must be replicated by the needle trajectory. If the beam can pass through, the needle will make its way through the same passage to the target. With the aid of a built-in caliper on the ultrasound machine, the depth to the epidural space can be measured as the distance from the skin to the ventral border of the LF-D unit (Fig. 7). It is advisable to measure the depth in the transverse plane and also to confirm the measurement with scanning in the paramedian plane. It should be noted that the depth to the epidural space continues to increase as we scan down from the L1-2 to the L5-S1 interspace. Also, the measured depth does not differ significantly between the transverse and the paramedian longitudinal scanning planes, although it could be a few millimetres less in the latter. The information obtained from these two planes can complement each other and therefore be used alternatively for the overall spine assessment. Measuring the anteroposterior diameter of the dural sac can provide added information if a spinal or a combined spinal-epidural technique is planned. Of note, ultrasound examination does not preclude the need for lossof-resistance testing for epidural space localization.

The continuity of the LF-D unit in a given interspace is an important marker of an ideal image. Lack of visibility of this unit or its disrupted image indicates an atypical image. Sonograms obtained in the transverse plane above the L3-4 interspace appear typical; however, up to $29 \%$ of images appear atypical when scanning is performed in the lower lumbar interspaces. ${ }^{7}$ Perhaps this occurrence could be related to poor acoustic windows or technical difficulties encountered at these levels in the transverse plane. Sometimes a residual shadow of the spinous process can project over the ligamentum flavum in the midline and interrupt the continuity of the ligamentum flavum. Usually this situation can be rectified by changing the angle of the probe slightly.

In all the lumbar interspaces, the sonograms obtained in the paramedian longitudinal plane are clearly superior in quality compared with those obtained in the transverse plane. This is likely due to a wider acoustic window in this 

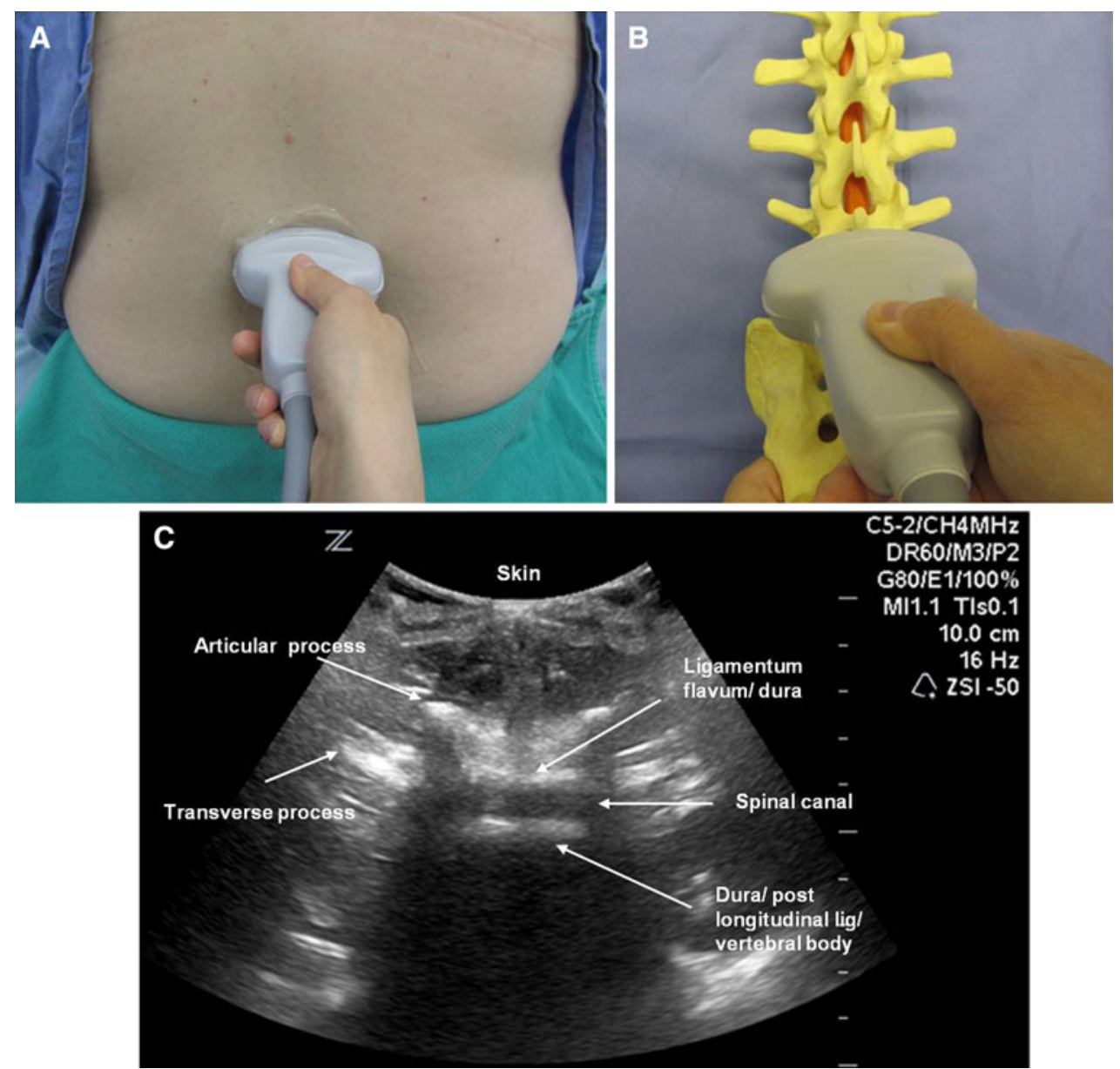

Fig. 3 (A) Scanning in the transverse plane; (B) Probe oriented perpendicular to the axis of spine model; (C) Typical sonogram of a lumbar interspace: midline hyperechoic structures represent the ligamentum flavum-dorsal dura unit (upper) and the ventral duraposterior longitudinal ligament-vertebral body complex (lower); bilateral symmetrical hyperechoic structures indicate articular and transverse processes with their acoustic shadows

plane. ${ }^{4,7}$ Therefore, scanning in this plane can be used to verify the findings of the transverse plane or to obtain additional information.

\section{Abnormal sonoanatomy}

Patients with morbid obesity, scoliosis and spinal instrumentation pose a considerable challenge for the placement of neuraxial block; however, diagnostic lumbar ultrasound in these patients can provide valuable information in choosing or avoiding a given interspace.

\section{Obesity}

In obese patients, poor resolution of the image is common due to the presence of subcutaneous fat and deeply
Fig. 3 (A) Balayage dans le plan transverse; (B) Sonde orientée de façon perpendiculaire à l'axe du modèle de la colonne; (C) Sonogramme typique d'un espace interlombaire: les structures hyperéchogènes médianes représentent l'unité ligament jaune - dure-mère dorsale (ligamentum flavum/dura) et le complexe dure-mère ventrale - ligament longitudinal postérieur - corps vertébral (dura/post longitudinal lig/ vertebral body); les structures hyperéchogènes symétriques bilatérales indiquent les apophyses articulaires (articular process) et transverses (transverse process) avec leurs ombres acoustiques

located target structures. When the landmarks are difficult to palpate, ultrasound can be extremely helpful to locate the midline by imaging the spinous process in the transverse plane. If the ligamentum flavum is deeply located, it may be poorly visualized in the transverse plane. In such instances, scanning should be done in the paramedian longitudinal plane to verify the findings and to determine if an optimum image can be obtained in this plane. That being the case, the LF-D unit can be centred on the screen and the interspace can be marked at the centre of the lateral side of the probe, while the shadow of the spinous process in the transverse plane can be used to mark the midline of the spine. Thus, the insertion point for midline puncture can be determined alternatively by joining the extensions of these two marks. A gap between two spinous processes can also be used as a surrogate for the 

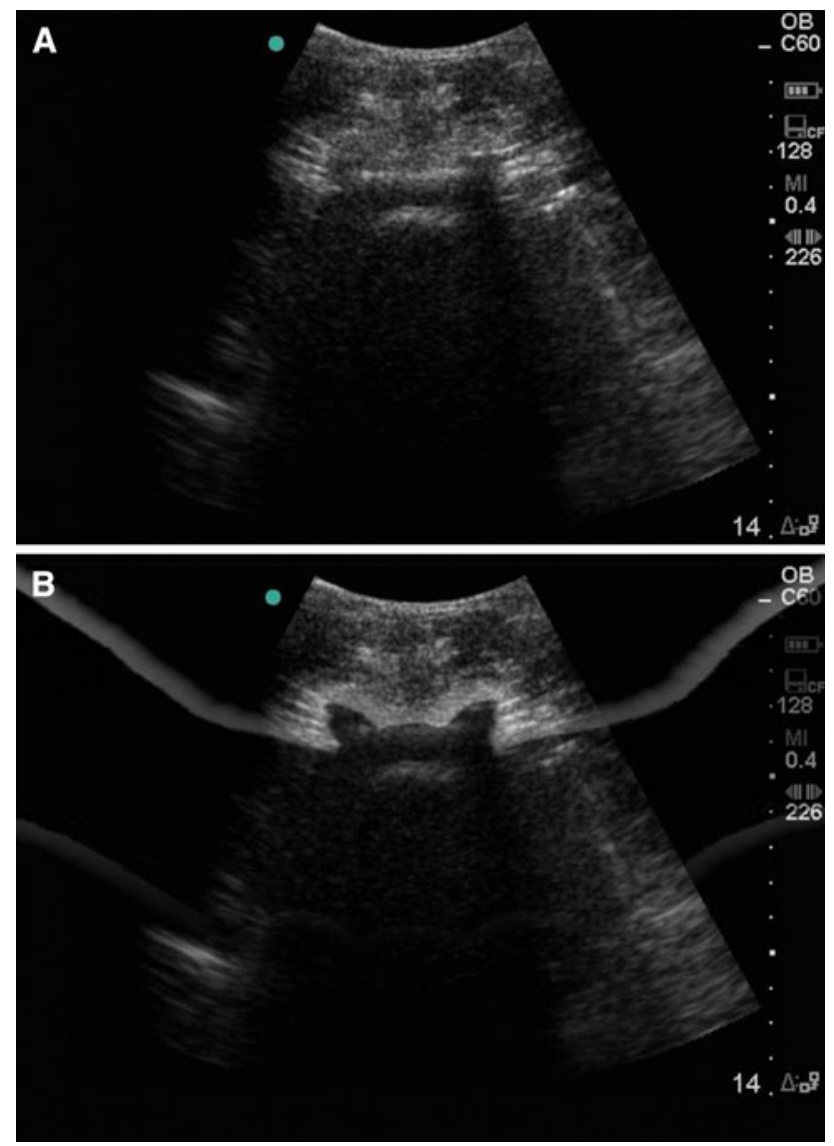

Fig. 4 (A) Ultrasound image of a typical lumbar interspace in the transverse plane; (B) Artist's rendition resembling a flying bat (From: Carvalho JCA. Ultrasound facilitated epidurals and spinals in obstetrics. Anesthesiol Clin 2008; 26: 145-58, with permission from Elsevier Science Ltd., Langford Lane, Kindlington, UK)

Fig. 4 (A) Image échographique d'un interespace lombaire typique dans le plan transverse; B) rendu artistique ressemblant à une chauve-souris en vol (tiré de: Carvalho JCA. Ultrasound facilitated epidurals and spinals in obstetrics. Anesthesiol Clin 2008; 26: 145-58, avec la permission de Elsevier Science Ltd., Langford Lane, Kindlington, UK)

interspace if the ligamentum flavum is too deep to be visualized.

In these patients, the greater degree of subcutaneous tissue compression by the ultrasound transducer may lead to an underestimation of the depth to the epidural space. This factor may provide some margin of safety by minimizing the risk of accidental dural puncture. For accurate measurement of the depth, it may be advisable to release the pressure on the transducer after obtaining an optimized image. In most cases, the measured depth to the epidural space is less than $8 \mathrm{~cm}$; however, it may be more in extreme situations. Consequently, unless the ultrasound predicts a depth of more than $8 \mathrm{~cm}$, it seems appropriate to use a standard needle to identify the epidural space in the majority of these patients. ${ }^{8}$

Additional factors that require more attention in this subset of patients include appropriate patient position,

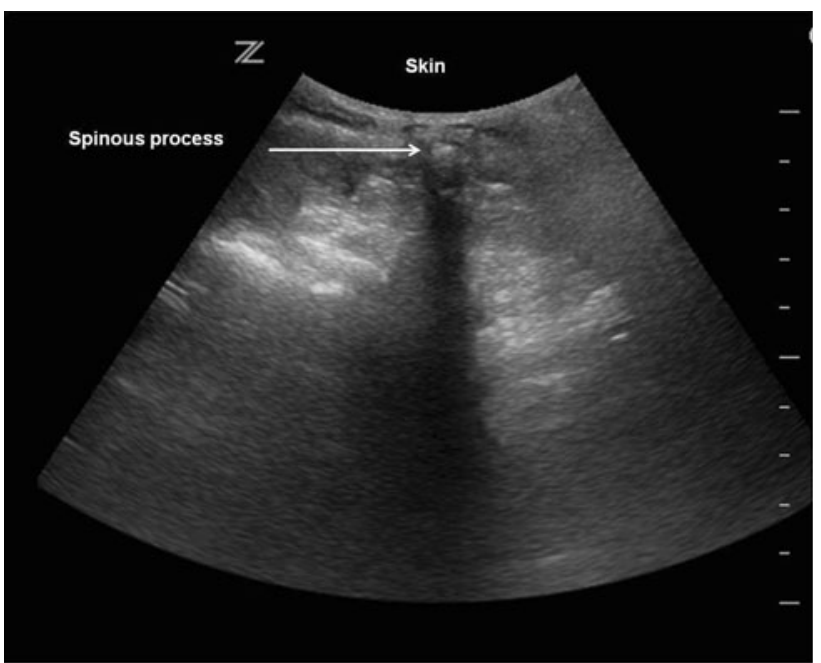

Fig. 5 Ultrasound image in the transverse plane showing a hyperechoic spinous process below the skin and a vertical dark acoustic shadow underneath

Fig. 5 Image échographique dans le plan transverse montrant une apophyse épineuse (spinous process) hyperéchogène au-dessous de la peau et une ombre acoustique sombre verticale dessous

meticulous skin markings, and careful visualization of the transducer angle. Owing to increased depth to the epidural space in these patients, a small-angle change at the skin surface can result in a significant change in the needle trajectory, requiring needle redirection or reinsertion.

\section{Scoliosis}

Patients with scoliosis may have axial rotation of the vertebral bodies and angulation of spinous processes. The sonographic image in these patients can reveal the location of the spinous process lateral to the virtual midline of the patient, asymmetry of the articular and transverse processes, and discontinuous ligamentum flavum in the transverse plane. In such situations, several interspaces should be scanned, and the interspace with normal sonoanatomy and continuous ligamentum flavum should be chosen for the neuraxial block. The degree of rotation of the spine can be estimated by rotating the ultrasound transducer in the transverse plane until the ligamentum flavum appears horizontally levelled on the ultrasound image. If this space must be selected for the block, the angulation of the transducer must correspond to the degree of rotation of the vertebral bodies to provide guidance for the needle direction. ${ }^{9}$

\section{Spinal instrumentation}

Patients with major spinal instrumentation are often denied the advantages of neuraxial blocks due to a high failure rate 
Fig. 6 Marking skin insertion point in the transverse plane: (A) Vertical line marking the midline; (B) horizontal line marking the interspace; and (C) skin insertion point at the intersection of these lines Fig. 6 Marquage du point d'insertion sur la peau dans le plan transverse: (A) ligne verticale marquant la ligne médiane; (B) ligne horizontale marquant l'espace interépineux; et (C) point d'insertion sur la peau à l'intersection de ces lignes
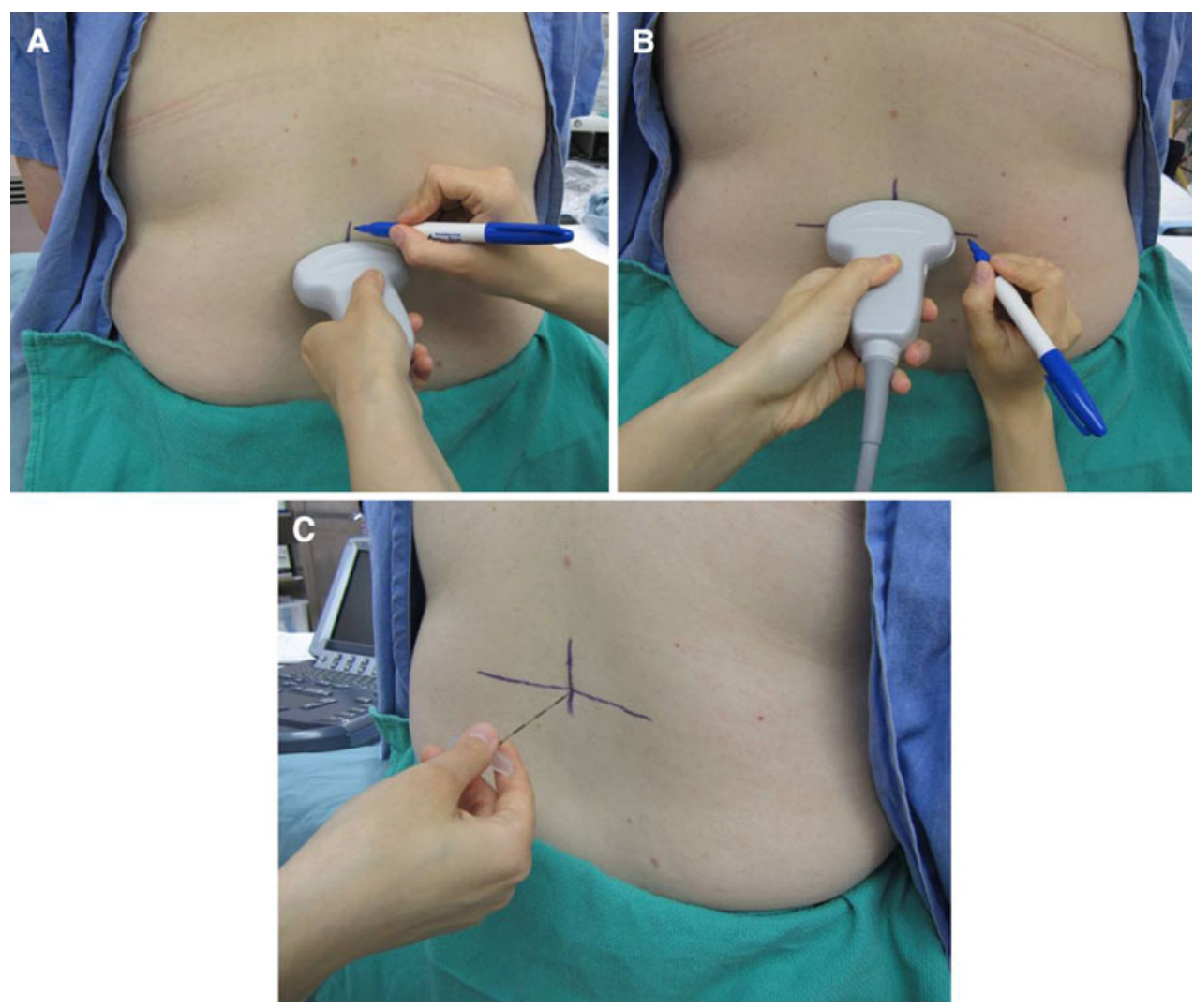

and risk of complications. In these patients, destruction of bones and soft tissues, bone grafting, and placement of rods and screws can obscure the anatomical as well as the sonographic landmarks. However, with ultrasonography, it is now possible to perform a regional technique by identifying the interspace with preserved anatomy. ${ }^{10}$

\section{Efficacy of ultrasound-guided techniques}

One of the prime indications of spinal ultrasound is the identification of the lumbar intervertebral levels. It is important to identify levels accurately and to choose a level below conus medullaris during spinal anesthesia to prevent spinal cord trauma. ${ }^{11}$ Broadbent et al. demonstrated that even experienced anesthesiologists estimate the intervertebral level inaccurately by palpation in $71 \%$ of cases; they tend to estimate the level as higher than the actual, and their estimate could be as many as four spaces higher. ${ }^{12}$ Tuffier's line, an anatomical landmark widely used for this purpose, does not always bear a constant relationship to an individual vertebral level or the interspace. Particularly in pregnant women, Tuffier's line intersects the spine above L4-5 interspace level, and the median level of intersection is just below L2-3 level. ${ }^{13}$ Furthermore, it can be more difficult to identify in obese women. Another factor to consider is the inconsistent location of the tip of the conus medullaris with respect to the vertebral level, which lies below L1-2 in about $42 \%$ of adults. ${ }^{12}$ With ultrasound imaging, intervertebral levels can be identified with more precision. Its accuracy has been shown to be about $76 \%$ compared with $30 \%$ accuracy with palpation. ${ }^{14}$

Arzola et al. observed that there was no need to reinsert the needle in $92 \%$ of the patients when pre-puncture ultrasound was used for epidural placement, and there was no need to even redirect the needle in $74 \%$ of the patients. The successful identification of the epidural space was accomplished with two or fewer redirections in $97 \%$ of the cases. ${ }^{5}$ Similarly in obese parturients, we noted that three or fewer redirections were required in $93 \%$ of cases for successful placement of epidural catheters through an ultrasound-determined insertion point. ${ }^{8}$ In various studies in obstetric patients, Grau et al. demonstrated that ultrasound guidance improved the success of block, minimized the complication rate, and improved overall patient satisfaction when compared with the conventional palpatory method. Such outcomes were also found in patients with anticipated difficult epidurals (Table 1). ${ }^{15-18}$ Several studies involving obstetric patients have shown an excellent correlation between the ultrasound estimated depth to the 


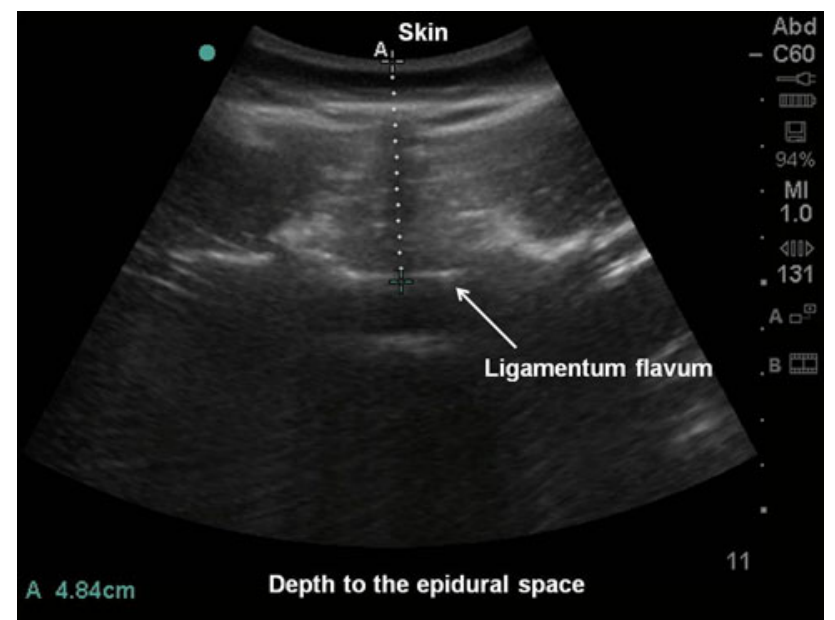

Fig. 7 Image in the transverse plane showing the depth to the epidural space measured with the help of built-in calipers as the distance from the skin to the ventral border of the ligamentum-dura unit

Fig. 7 Image dans le plan transverse montrant la profondeur de l'espace péridural. La distance entre la peau (skin) et la limite ventrale de l'unité ligament jaune - dure-mère (ligamentum flavum) est mesurée à l'aide de graduations intégrées

epidural space and the actual needle depth. The expected depth to the epidural space can be predicted within a range of $\pm 0.7 \mathrm{~cm}$ in non-obese parturients and $\pm 1 \mathrm{~cm}$ in obese parturients with a $95 \%$ confidence interval (Table 2). . $^{\text {, }, 15-17,19-21}$

The concerns regarding the longer time required to perform the epidural with the use of ultrasound are overstated, as the technique actually leads to fewer attempts at successful epidural placement and therefore is likely to reduce overall procedure time in patients with difficult anatomic landmarks. It usually takes an average of 2-3 minutes for the ultrasound assessment of the spine. ${ }^{15-17}$
Ultrasound as a teaching tool

Ultrasound imaging has a potential role in teaching and improving the learning curves of anesthesia trainees for epidural insertion. Grau et al. observed a higher success rate and steeper rise in the learning curve of the group that performed ultrasound-guided epidurals compared with the group that learned epidural insertion in the conventional manner. ${ }^{22}$ Our group observed that novices required a great deal of practice to perfect the technique of lumbar ultrasound even after attending the lectures and workshops. More than 20 attempts are required to master critical tasks necessary for locating accurate ultrasound landmarks. Commonly observed errors include missing the L5-S1 space, not marking the skin meticulously and inadvertently sliding the transducer to a lower segment while marking the skin insertion point. Careful attention to these aspects should likely improve the ultrasound learning curve. ${ }^{23}$ Thus, ultrasound should not be reserved for technically difficult cases because it requires experience in routine cases with easily identified palpable landmarks before it can be used effectively in difficult cases.

\section{Real-time ultrasound}

Real-time ultrasound scanning can be performed as an out-of-plane technique by scanning in the paramedian longitudinal approach and inserting the epidural needle in the midline. ${ }^{18}$ The obvious limitations of this technique include poor demarcation of individual structures, such as the ligamentum flavum and the dura mater, and the need for an assistant to perform scanning. However, the use of epidural syringes with automated loss-of-resistance

Table 1 Efficacy of ultrasound-guided neuraxial blocks

\begin{tabular}{|c|c|c|c|c|c|}
\hline \multirow[t]{2}{*}{ Study } & \multirow[t]{2}{*}{ Patients } & \multirow[t]{2}{*}{ Parameters tested } & \multicolumn{3}{|l|}{ Findings } \\
\hline & & & US & Control & $P$ value \\
\hline \multirow[t]{3}{*}{ Grau $^{15}$} & \multirow[t]{3}{*}{ Labouring women $(n=300)$} & Puncture attempts $(n)$ & $1.4 \pm 0.7$ & $2.2 \pm 1.1$ & $<0.013$ \\
\hline & & Effective analgesia & $98 \%$ & $92 \%$ & $<0.03$ \\
\hline & & Side effects & $20 \%$ & $34 \%$ & $<0.011$ \\
\hline \multirow[t]{2}{*}{ Grau $^{16}$} & \multirow[t]{2}{*}{$\operatorname{CSE}$ for $\mathrm{CD}(n=80)$} & Puncture attempts $(n)$ & $1.3 \pm 0.5$ & $2.1 \pm 0.9$ & $<0.001$ \\
\hline & & Success in first attempt & $75 \%$ & $20 \%$ & $<0.001$ \\
\hline \multirow[t]{2}{*}{$\operatorname{Grau}^{17}$} & \multirow[t]{2}{*}{ Labouring women with poor landmarks $(n=72)$} & Puncture attempts $(n)$ & $1.5 \pm 0.9$ & $2.6 \pm 1.4$ & $<0.001$ \\
\hline & & Epidural failure & $0 \%$ & $5.5 \%$ & $<0.03$ \\
\hline $\mathrm{Grau}^{18}$ & CSE for $\mathrm{CD}(n=30)$ & Success at first attempt & $70 \% *$ & $40 \%$ & $<0.036$ \\
\hline Arzola $^{5}$ & Labouring women $(n=60)$ & Success at first attempt & $92 \%$ & - & - \\
\hline Balki $^{8}$ & Labouring obese women $(n=46)$ & Success at first attempt & $76 \%$ & - & - \\
\hline
\end{tabular}

US = ultrasound; CSE = combined spinal-epidural; CD = Cesarean delivery; $n=$ number of patients. *Success rate was $100 \%$ for epidurals performed with real-time US 
Table 2 Ultrasound-estimated depth to the epidural space in obstetric patients

\begin{tabular}{|c|c|c|c|c|c|}
\hline Study & Patients & Scanning plane & $\begin{array}{l}\text { Puncture } \\
\text { Depth }(\mathrm{cm})\end{array}$ & $\begin{array}{l}\text { Correlation } \\
\text { Coefficient }\left(r^{2}\right)\end{array}$ & $\begin{array}{l}\text { Bland-Altmann } \\
\text { Analysis } \\
\text { Precision }(\mathrm{cm})\end{array}$ \\
\hline Currie $^{19}$ & Labour epidurals $(n=75)$ & Sagittal & $4.1 \pm 0.8$ & 0.92 & 0.54 \\
\hline Wallace $^{20}$ & Labour epidurals in obese $(n=36)$ & Sagittal median/ Transverse & $5.5 \pm 2.1$ & 0.98 & 0.54 \\
\hline $\mathrm{Grau}^{21}$ & Labour epidurals $(n=100)$ & Sagittal paramedian/ Transverse & $5.3 \pm 0.7$ & 0.79 & 0.68 \\
\hline $\mathrm{Grau}^{16}$ & CSE for $\operatorname{CD}(n=40)$ & Sagittal paramedian/ Transverse & $5.2 \pm 0.9$ & 0.92 & 0.51 \\
\hline $\mathrm{Grau}^{17}$ & $\begin{array}{l}\text { Labour epidurals in difficult } \\
\text { cases }(n=36)\end{array}$ & Sagittal paramedian/ Transverse & $5.8 \pm 1.1$ & 0.87 & 0.77 \\
\hline $\mathrm{Grau}^{15}$ & Labour epidurals $(n=150)$ & Sagittal Paramedian/ Transverse & $5.1 \pm 0.9$ & 0.83 & 0.69 \\
\hline Arzola $^{5}$ & Labour epidurals $(n=60)$ & Transverse & $4.7 \pm 0.7$ & 0.88 & 0.70 \\
\hline $\mathrm{Balki}^{8}$ & Labour epidurals in obese $(n=46)$ & Transverse & $6.6 \pm 1.0$ & 0.85 & 1.00 \\
\hline
\end{tabular}

$\mathrm{CSE}=$ combined spinal-epidural; $\mathrm{CD}=$ Cesarean delivery; $n=$ number of patients

function may well allow a single skilled operator to perform the real-time ultrasound-guided epidural procedure. Eventually, with the improvement in ultrasound technology and development of needle guidance devices, this milestone too can be achieved sooner rather than later.

\section{Conclusion}

Ultrasound has several potential advantages in the placement of spinal and epidural blocks in obstetric patients. With increased availability of this technology, appropriate training, and increased awareness amongst the anesthesia community, ultrasound should become more accessible to obstetric patients.

\section{Clinical case}

A 29 -yr-old term gravida 2 para 1 (G2P1) woman presents to the labour and delivery unit in early labour and requests epidural labour analgesia. Her previous labour culminated in a vaginal delivery, and her current antenatal course has been uneventful. Unfortunately, her previous epidural experience was complicated; it required multiple attempts and involved an accidental dural puncture that resulted in a severe post-dural puncture necessitating a blood patch. She is understandably anxious about the epidural experience. She is $160 \mathrm{~cm}$ tall and weighs $85 \mathrm{~kg}$, and examination of her lumbar back reveals that her spinous processes are neither visible nor easily palpable. You decide to utilize ultrasound to identify the landmarks prior to epidural placement.
Instructions for completing the continuing professional development (CPD) module:

1. Read the current article and the references indicated in bold.

2. Go to: https://www.cpass2.umontreal.ca/selfassessment program/ and select the current module (Locating the epidural space in obstetric patients: ultrasound a useful tool).

3. Answer the multiple choice questions regarding the case scenario.

4. Once you have entered all of your answers, you will have access to experts' explanations for all the possible choices.

5. Participants may claim up to four hours of CPD, for a total of eight credits under Section 3 of the CPD program of the Royal College of Physicians and Surgeons of Canada.

\section{L'échoguidage, un outil utile pour localiser l'espace péridural chez les patientes en obstétrique}

\author{
Article de synthèse \\ Objectif Ce module de développement professionnel \\ continu a pour but de décrire le rôle de l'échoguidage pour \\ établir la démarcation de la colonne avant de positionner \\ les blocs neuraxiaux, ainsi que d'offrir une approche \\ systématique complète pour l'utilisation de l'échographie \\ chez les patientes en obstétrique.
}


Constatations principales Il a été observé que l'imagerie ultrasonographique de la colonne lombaire était efficace pour améliorer le taux de réussite de blocs neuraxiaux chez les patientes en obstétrique. Le taux de réussite à la première tentative d'insertion péridurale échoguidée est de 30 à $60 \%$ plus élevé que celui de la méthode péridurale traditionnelle. L'échogramme pré-ponction peut fournir des données fiables et précises sur plusieurs facteurs critiques dont il est nécessaire de tenir compte pour positionner adéquatement la péridurale, comme le niveau intervertébral, la ligne médiane de la colonne, le point de ponction optimal, l'angle optimal d'insertion de l'aiguille et la profondeur de l'espace péridural. Le balayage échographique de la colonne lombaire permet d'obtenir des images avec deux caractéristiques distinctes: l'une dans le plan transverse, rappelant une "chauve-souris en vol ", et l'autre dans le plan longitudinal paramédian, illustrant une configuration en «dents de scie». Les deux plans permettent de voir le ligament jaune et la dure-mère, ainsi que d'autres points de référence osseux contigus. Une méthode de balayage progressif peut être un guide utile pour ce qui est de faciliter la réussite du positionnement de l'aiguille tant pour les patientes présentant une anatomie normale de la colonne vertébrale que pour celles présentant une anatomie anormale.

Conclusion Le fait d'intégrer l'utilisation de l'échogramme de la colonne lombaire à la pratique clinique quotidienne pourrait accrottre la facilité d'exécution des péridurales, et contribuer à la sécurité et au confort des patientes.

\section{Objectifs de ce module de développement professionnel continu}

Après avoir lu ce module, le lecteur sera en mesure de:

1. Comprendre les principes de l'imagerie par ultrason et de l'interprétation de la sonoanatomie de la colonne lombaire chez les patientes en obstétrique;

2. Identifier les images normales dans divers plans de balayage et déterminer leurs applications quant aux techniques d'analgésie rachidienne et péridurale;

3. Reconnaître les images de sonoanatomie chez les patients souffrant d'anomalies de la colonne vertébrale et d'obésité morbide; et

4. Discuter de l'influence potentielle de l'approche échoguidée pour améliorer la qualité et l'innocuité des blocs neuraxiaux.

L'échoguidage offre de nombreuses applications dans la pratique de la médecine. En anesthésie, cette technologie a été associée à des avantages considérables pour l'exécution de blocs nerveux périphériques et l'installation de voies veineuses centrales. Par ailleurs, elle est couramment utilisée dans la pratique clinique pour guider les blocs neuraxiaux et peut grandement améliorer leur précision et leur efficacité. En 2008, le National Institute for Health and Clinical Excellence (NICE) du Royaume-Uni avait déjà publié des directives quant à l'utilisation de l'échoguidage pour le positionnement des cathéters périduraux. ${ }^{1}$

Pour les blocs neuraxiaux, la méthode traditionnelle implique une approche «à l'aveugle » fondée uniquement sur des points de repères anatomiques. Toutefois, ces points ne sont pas toujours évidents, ou mêmes précis. La situation peut devenir encore plus complexe, et la technique, plus incertaine, lorsque les points de repère anatomiques sont difficiles à palper en raison d'un problème d'obésité et/ou d'anomalies de la colonne vertébrale. Ce double problème (une approche à l'aveugle combinée à l'anatomie variable des patients) pourrait expliquer de nombreuses complications qui se manifestent pendant l'exécution de blocs neuraxiaux. Parmi ces complications, on compte des tentatives de ponction multiples, une insertion difficile, des traumatismes à diverses structures vitales et une ponction durale accidentelle. La technologie disponible à l'heure actuelle pourrait contribuer à l'innocuité et à l'efficacité des blocs neuraxiaux en « révélant » la cible et en fournissant des données vitales sur la structure de la colonne dans différents plans.

Cependant, l'utilisation fructueuse et sécuritaire de l'échoguidage dépend de la bonne compréhension de ses principes de base et de l'interprétation adéquate des images produites en fonction de l'anatomie pertinente. L'objectif de ce module consiste à fournir des directives quant à l'évaluation systématique de la colonne lombaire par échoguidage et d'illustrer une approche fondée sur des données probantes pour son utilisation.

\section{Principes de base de l'échographie rachidienne}

La première étape du processus de balayage systématique de la colonne lombaire consiste à choisir une sonde appropriée afin d'obtenir la meilleure image possible. Une sonde linéaire à haute fréquence (7 à $15 \mathrm{MHz})$ est privilégiée pour l'anesthésie des nerfs périphériques et la canulation veineuse centrale puisque les structures que l'on doit visualiser sont situées près de la surface. Cette sonde produit une image de haute résolution, mais ne pénètre pas en profondeur. Étant donné que les structures de la colonne vertébrale sont situées plus profondément, une sonde offrant une meilleure pénétration des ondes sonores est plus appropriée à l'échographie lombaire. On peut obtenir ce résultat en utilisant une sonde incurvée à basse 
fréquence ( 2 à $5 \mathrm{MHz}$ ou 3 à $6 \mathrm{MHz}$ ), bien que la résolution de l'image en souffrira. ${ }^{2}$ La surface incurvée de la sonde permet d'obtenir une image plus large et, ainsi de visualiser les structures anatomiques qui sont situées plus latéralement, comme les apophyses transverses. On recommande de régler la profondeur à 9 à $14 \mathrm{~cm}$ afin de voir toutes les structures pertinentes à la résolution optimale. Le faisceau mesure seulement $1 \mathrm{~mm}$ d'épaisseur et traverse la partie centrale de la sonde. Par conséquent, un angle d'incidence perpendiculaire aux structures visées est susceptible de produire une image de qualité optimale. L'angle de $90^{\circ}$ est le plus approprié parce que les ondes sont mieux réfléchies par les structures et renvoyées vers la sonde lorsque cet angle est privilégié.

L'échographie rachidienne est particulièrement complexe puisque malgré leur localisation peu profonde, les structures pertinentes au bloc neuraxial sont dissimulées par une cage vertébrale osseuse complexe. Les ondes ultrasonores ne traversent pas les os en raison de leur impédance acoustique élevée; ils nuisent donc à la visualisation des structures situées plus en profondeur. Les os sont intensément hyperéchogènes (clairs) sur l'image et créent des zones hypoéchogènes (sombres) appelées «ombres acoustiques». Lorsqu'on essaie d'obtenir une image des structures situées au-delà des os, il est donc nécessaire de trouver une «fenêtre acoustique », soit un espace entre les zones osseuses par lequel les ondes ultrasonores peuvent passer afin de visualiser les structures situées plus en profondeur. ${ }^{3}$ On peut obtenir deux fenêtres acoustiques en examinant la colonne lombaire par échogramme: la première, avec un plan transverse ou axial dans l'espace intervertébral, et la deuxième, avec un plan longitudinal paramédian ou sagittal dans l'espace interlaminaire. ${ }^{4,5}$

\section{Échographie de la colonne lombaire}

L'échogramme de la colonne lombaire peut être utilisé comme procédure «pré-ponction » afin d'identifier les points de repère, ou comme balayage «en temps réel » afin de produire des images dynamiques pendant l'exécution de la péridurale. À l'heure actuelle, on privilégie la méthode «pré-ponction » puisqu'elle est simple et facile à exécuter, en plus de fournir des données fiables. ${ }^{6}$ Il convient de s'assurer que la patiente se trouve dans la même position lors de l'échogramme et lors du positionnement de l'aiguille. Avec cette méthode, on peut obtenir les données suivantes: 1) le niveau intervertébral; 2) la ligne médiane de la colonne; 3 ) le point de ponction; 4) l'angle d'insertion de l'aiguille; et 5) la profondeur de l'espace péridural.
Plan longitudinal paramédian ou plan sagittal

Pour compter les niveaux intervertébraux via les fenêtres interlaminaires, on privilégie le plan obtenu en plaçant la sonde de façon longitudinale, parallèlement à la colonne vertébrale, à 2 ou $3 \mathrm{~cm}$ de la ligne médiane, et en la dirigeant vers le centre du canal rachidien. Avec ce plan longitudinal paramédian ou sagittal, on peut observer plusieurs niveaux dans une seule image. Parmi les structures sonoanatomiques visibles dans ce plan, on compte 1) le sacrum, 2) les lames vertébrales, 3) le ligament jaune et la dure-mère dorsale, qui apparaît habituellement comme une seule unité « ligament jaune-dure-mère » (LJ-D), et 4) la dure-mère ventrale (DV), le ligament longitudinal postérieur (LLP) et le corps vertébral (CV), qui apparaît comme un seul complexe DV-LLP-CV (Fig. 1, Vidéo 1). Il est impossible de distinguer les différents éléments de l'unité LJ-D et du complexe DV-LLP-CV avec les appareils d'ultrason présentement sur le marché.

En balayant dans ce plan, on déplace la sonde d'échographie vers la tête de la patiente en partant du niveau sacré. Sur l'image, à environ 3 à $5 \mathrm{~cm}$ sous la peau, on peut identifier l'extrémité supérieure du sacrum, qui apparaît comme une surface hyperéchogène plate et réfléchissante. En déplaçant la sonde vers le haut, on peut identifier l'espace intervertébral, qui apparaît comme un renfoncement de la surface réfléchissante. Cette image est suivie d'un tracé en «dents de scie», représente les lames vertébrales (les dents), interrompues par les espaces intervertébraux (Fig. 2, Vidéo 2). Chaque espace intervertébral est constitué de deux bandes hyperéchogènes parallèles, ou d'une signe " = » (égal), tandis que l'unité LJ-D est représentée par la bande externe, et le complexe DV-LLP-CV, par la bande plus profonde. Le niveau interépineux visé peut être identifié en comptant les lames vertébrales et les espaces intervertébraux correspondants. On peut également déterminer le centre d'un espace intervertébral en le plaçant au centre de l'écran.

\section{Plan transverse ou axial}

Une fois le niveau adéquat choisi dans le plan longitudinal paramédian, on y place la sonde perpendiculairement à l'axe de la colonne pour obtenir une image de l'ensemble de l'espace intervertébral. On peut y voir les structures suivantes: 1) l'unité LJ-D, 2) le complexe DV-LLP-CV, 3) les apophyses articulaires, et 4) les apophyses transverses (Fig. 3, Vidéo 3).

Sur l'image, l'unité LJ-D et le complexe DV-LLP-CV apparaissent comme des structures médianes qui forment un signe «=» hyperéchogène au milieu de l'espace intervertébral. Les apophyses articulaires et transverses forment les structures hyperéchogènes symétriques et 
bilatérales. Les apophyses transverses apparaissent comme des prolongements latéraux des réflexions de l'unité LJ-D. On dit que l'image typique obtenue dans le plan transverse ressemble à une « chauve-souris en vol ${ }^{6}$ (Fig. 4). Lorsque la sonde est déplacée vers le haut ou vers le bas de l'espace intervertébral, on peut voir l'apophyse épineuse supérieure ou inférieure; on peut donc déterminer que la ligne médiane de la colonne vertébrale est l'apophyse épineuse. Sous la peau, celle-ci forme un signal hyperéchogène souligné d'une ombre triangulaire hypoéchogène (Fig. 5). Par conséquent, le balayage dans ce plan peut permettre d'identifier la ligne médiane de la colonne vertébrale et le milieu de l'espace intervertébral.

Données cliniques obtenues à partir de l'échogramme lombaire

Une fois que l'on a obtenu la meilleure image possible des structures contenues dans l'espace intervertébral ou que le signe « = » apparaît dans le plan transverse et le plan longitudinal paramédian, l'image est placée au centre de l'écran et figée. On place une marque sur la peau au centre des faces supérieure et latérale de la sonde, tout en gardant celle-ci immobile. Ensuite, on retire la sonde et on relie les marques par des lignes. Le point d'insertion est déterminé par l'intersection de ces deux lignes (Fig. 6). Il est donc possible de déterminer le point d'insertion des ponctions médiane et paramédiane par échoguidage dans le plan transverse et dans le plan longitudinal paramédian, respectivement. Étant donné que les ponctions médianes sont couramment utilisées chez les patientes en obstétrique, on privilégie l'approche transverse pour déterminer le point d'insertion.

De plus, la trajectoire de l'aiguille doit être identique à l'angle de la sonde offrant la meilleure image des structures de l'espace intervertébral. Si le faisceau peut traverser, l'aiguille suivra le même chemin pour atteindre sa cible. À l'aide des graduations intégrées à l'appareil d'échographie, on peut mesurer la profondeur de l'espace péridural, qui correspond à la distance entre la peau et la limite ventrale de l'unité LJ-D (Fig. 7). Il est recommandé de mesurer la profondeur dans le plan transverse et de confirmer la mesure obtenue en balayant dans le plan paramédian. Notons que la profondeur de l'espace péridural augmente au fur et à mesure que l'on descend de l'espace L1-L2 à l'espace L5-S1. De plus, la profondeur mesurée ne varie pas de façon significative entre le plan de balayage transverse et le plan de balayage longitudinal paramédian, bien qu'elle puisse être de quelques millimètres plus courte dans le second. Les données recueillies à partir de ces deux plans se complètent et peuvent donc être utilisées en alternance pour l'évaluation globale de la colonne vertébrale. Le fait de mesurer le diamètre antéropostérieur du sac dural peut permettre d'obtenir d'autres renseignements si on prévoit d'utiliser une technique rachidienne ou une combinaison des techniques rachidienne et péridurale. Il convient également de noter que l'examen échoguidé n'élimine pas la nécessité d'évaluer la perte de résistance pour localiser l'espace péridural.

La continuité de l'unité LJ-D dans un espace intervertébral donné est un facteur important permettant d'identifier une image idéale. Une mauvaise visibilité de cette unité ou une image discontinue signifie une image atypique. Les sonogrammes obtenus dans le plan transverse au-dessus de l'espace intervertébral L3-L4 semblent atypiques; toutefois, jusqu'à $29 \%$ des images obtenues peuvent sembler atypiques lorsque l'échoguidage est réalisé dans les espaces intervertébraux situés plus bas. ${ }^{7}$ Ceci est peut-être dû à une mauvaise fenêtre acoustique ou à des difficultés techniques rencontrées à ces niveaux dans le plan transverse. Parfois, une ombre résiduelle de l'apophyse épineuse peut se superposer au ligament jaune dans la ligne médiane et en interrompre la continuité. En règle générale, on peut y remédier en modifiant légèrement l'angle de la sonde.

Dans tous les espaces intervertébraux lombaires, les sonogrammes obtenus dans le plan longitudinal paramédian sont d'une qualité bien supérieure à ceux obtenus dans le plan transverse, ce qui résulte probablement d'une fenêtre acoustique plus large. ${ }^{4,7}$ Par conséquent, le balayage dans ce plan peut être utilisé pour vérifier les données recueillies dans le plan transverse ou pour obtenir des données supplémentaires.

\section{Sonoanatomie anormale}

Les patientes souffrant d'obésité morbide, d'une scoliose et lorsque l'échoguidage est réalisé d'une instrumentation rachidienne présentent un défi de taille pour l'exécution du bloc neuraxial. Cependant, l'examen ultrasonographique peut alors fournir des données précieuses qui permettront de choisir un espace intervertébral donné ou de l'éviter.

\section{Obésité}

Chez les patientes obèses, une mauvaise résolution de l'image est courante en raison de la présence de tissus adipeux sous-cutanés et de la profondeur des structures cibles. Lorsque les points de repère sont difficiles à palper, l'échographie peut se révéler extrêmement utile pour localiser la ligne médiane par l'imagerie de l'apophyse épineuse dans le plan transverse. Si le ligament jaune est situé en profondeur, il peut toutefois être difficile à visualiser dans ce même plan. Dans ce cas, le balayage devrait être effectué dans le plan longitudinal paramédian afin de vérifier les constations et de déterminer s'il peut être utilisé pour obtenir une image optimale. Si c'est le cas, on 
peut placer l'unité LJ-D au centre de l'écran et marquer l'espace intervertébral au centre de la face latérale de la sonde, tandis que l'ombre de l'apophyse épineuse dans le plan transverse peut être utilisée pour marquer la ligne médiane de la colonne vertébrale. Par conséquent, l'intersection du prolongement de ces deux marques devient alors une autre façon de déterminer le point d'insertion pour la ponction médiane. On peut également utiliser le creux entre deux apophyses épineuses comme indice de l'espace intervertébral si le ligament jaune est trop profond pour être visualisé.

Chez ces patientes, le degré plus élevé de compression des tissus sous-cutanés par la sonde peut mener à une sous-estimation de la profondeur de l'espace péridural. Ce facteur offre une certaine marge de sécurité en minimisant le risque de ponction durale accidentelle. Pour mesurer la profondeur avec précision, il est recommandé de diminuer la pression sur la sonde après avoir obtenu une image optimisée. Dans la plupart des cas, la profondeur mesurée de l'espace péridural est inférieure à $8 \mathrm{~cm}$, quoiqu'elle puisse être plus grande dans les cas extrêmes. Sauf si le balayage prévoit une profondeur de plus de $8 \mathrm{~cm}$, une aiguille standard semble donc appropriée pour identifier l'espace péridural chez la majorité de ces patientes. ${ }^{8}$

Parmi les autres facteurs devant faire l'objet d'une plus grande attention dans ce sous-ensemble de patientes, on retrouve la position appropriée de la patiente, la précision des marques sur la peau et la visualisation attentive de l'angle de la sonde. En raison de la profondeur plus importante de l'espace péridural chez ces patientes, une légère modification de l'angle à la surface de la peau peut provoquer un changement important de la trajectoire de l'aiguille, ce qui forcerait le réalignement ou la réinsertion de l'aiguille.

\section{Scoliose}

Les patientes souffrant d'une scoliose peuvent présenter une rotation axiale des corps vertébraux et une angulation des apophyses épineuses. Dans ces cas, l'image sonographique peut permettre de localiser l'apophyse épineuse latérale à la ligne médiane virtuelle de la patiente, l'asymétrie des apophyses articulaires et transverses, ainsi que la discontinuité du ligament jaune dans le plan transverse. On devrait alors balayer plusieurs espaces intervertébraux, et l'espace présentant une sonoanatomie normale et un ligament jaune continu devrait être choisi pour le bloc neuraxial. Le degré de rotation de la colonne peut être estimé en tournant la sonde dans le plan transverse jusqu'à ce que le ligament jaune apparaisse à l'horizontal sur l'image. Si l'on doit choisir cet espace pour le bloc, l'angle de la sonde doit correspondre au degré de rotation des corps vertébraux afin de guider la trajectoire de l'aiguille. ${ }^{9}$
Instrumentation rachidienne

Les patientes souffrant d'une instrumentation rachidienne majeure se voient souvent refuser les avantages des blocs neuraxiaux en raison d'un taux d'échec plus élevé et du risque de complications. Chez ces patientes, la destruction des os et des tissus mous, ainsi que la présence de greffes osseuses, de tiges et de vis peuvent nuire à la visibilité des points de repère anatomiques et échographiques. Cependant, avec l'ultrasonographie, il est maintenant possible d'exécuter une technique régionale en identifiant l'espace intervertébral qui a une anatomie préservée. ${ }^{10}$

\section{Efficacité des techniques échoguidées}

L'une des principales indications pour l'utilisation de l'échographie rachidienne est l'identification des niveaux intervertébraux de la colonne lombaire. Il est important d'identifier ces niveaux de façon précise et de choisir un niveau au-dessous du cône médullaire pendant la rachianesthésie. Ceci permet d'éviter un traumatisme au niveau de la moelle épinière. ${ }^{11}$ Broadbent et coll. ont démontré que, dans $71 \%$ des cas, même des anesthésiologistes d'expérience estimaient de façon erronée le niveau intervertébral par palpation; en effet, ils ont tendance à estimer le niveau comme étant plus élevé qu'en réalité, et leurs estimations peuvent s'écarter du niveau réel jusqu'à quatre espaces plus haut. ${ }^{12}$ La ligne de Tuffier, un repère anatomique communément utilisé à cette fin, ne correspond pas systématiquement à un niveau vertébral ou à un espace interépineux en particulier. C'est particulièrement le cas chez les femmes enceintes, où la ligne de Tuffier rejoint la colonne au-dessus du niveau intervertébral L4-5, et le niveau médian d'intersection se situe juste au-dessous du niveau L2-3. ${ }^{13}$ Cette ligne peut également être plus difficile à repérer chez les femmes obèses. Un autre facteur dont il faut tenir compte est l'emplacement changeant du cône médullaire par rapport au niveau vertébral, qui se situe au-dessous de L1-2 chez environ $42 \%$ des adultes. ${ }^{12}$ L'imagerie par ultrason permet d'identifier les niveaux intervertébraux avec davantage de précision. Il a été démontré que sa précision était d'environ $76 \%$ par rapport à une précision de $30 \%$ avec une méthode de palpation. ${ }^{14}$

Arzola et coll. ont observé qu'il n'était pas nécessaire de réinsérer l'aiguille chez $92 \%$ des patientes lorsqu'une échographie pré-ponction avait été réalisée pour le positionnement de la péridurale, et qu'il n'était même pas nécessaire de réorienter l'aiguille chez $74 \%$ des patientes. Dans $97 \%$ des cas, l'identification de l'espace péridural a réussi après deux réorientations ou moins de l'aiguille. ${ }^{5} \mathrm{De}$ la même manière, chez les parturientes obèses, nous avons noté que trois réorientations ou moins étaient nécessaires 
dans $93 \%$ des cas pour bien positionner les cathéters périduraux en utilisant un point d'insertion défini par ultrason. ${ }^{8}$ Dans plusieurs études réalisées chez des parturientes, Grau et coll. ont démontré que l'échoguidage améliorait la réussite du bloc, réduisait le taux de complications et améliorait la satisfaction globale des patientes par rapport à une méthode traditionnelle par palpation. De tels résultats ont également été observés chez des patientes pour lesquelles des péridurales difficiles étaient anticipées (Tableau 1) ${ }^{15-18}$ Plusieurs études portant sur des parturientes ont montré une excellente corrélation entre la profondeur de l'espace péridural estimée par ultrason et la profondeur réelle de l'aiguille. La profondeur anticipée de l'espace péridural peut être prédite avec une exactitude de $\pm 0,7 \mathrm{~cm}$ chez les parturientes non obèses et de $\pm 1 \mathrm{~cm}$ chez les parturientes obèses, avec un intervalle de confiance de $95 \%$ (Tableau 2). . $^{5,15-17,19-21}$

Les inquiétudes en ce qui touche à la prolongation du temps requis à la réalisation d'une péridurale avec échoguidage ne sont pas justifiées; en réalité, cette technique réduit le nombre de tentatives nécessaires à une mise en place réussie de la péridurale et, par conséquent,

Tableau 1 Efficacité des blocs neuraxiaux échoguidés

\begin{tabular}{|c|c|c|c|c|c|}
\hline \multirow[t]{2}{*}{ Étude } & \multirow[t]{2}{*}{ Patientes } & \multirow[t]{2}{*}{ Paramètres testés } & \multicolumn{3}{|c|}{ Constatations } \\
\hline & & & US & Témoin & Valeur $P$ \\
\hline \multirow[t]{3}{*}{$\mathrm{Grau}^{15}$} & \multirow[t]{3}{*}{ Femmes en travail obstétrical $(n=300)$} & Tentatives de ponction $(n)$ & $1,4 \pm 0,7$ & $2,2 \pm 1,1$ & $<0,013$ \\
\hline & & Analgésie efficace & $98 \%$ & $92 \%$ & $<0,03$ \\
\hline & & Effets secondaires & $20 \%$ & $34 \%$ & $<0,011$ \\
\hline \multirow[t]{2}{*}{$\mathrm{Grau}^{16}$} & \multirow[t]{2}{*}{ PRC pour AC $(n=80)$} & Tentatives de ponction $(n)$ & $1,3 \pm 0,5$ & $2,1 \pm 0,9$ & $<0,001$ \\
\hline & & Réussite à la première tentative & $75 \%$ & $20 \%$ & $<0,001$ \\
\hline \multirow[t]{2}{*}{$\mathrm{Grau}^{17}$} & \multirow{2}{*}{$\begin{array}{l}\text { Femmes en travail obstétrical présentant } \\
\text { des repères médiocres }(n=72)\end{array}$} & Tentatives de ponction $(n)$ & $1,5 \pm 0,9$ & $2,6 \pm 1,4$ & $<0,001$ \\
\hline & & Échec de la péridurale & $0 \%$ & $5,5 \%$ & $<0,03$ \\
\hline $\mathrm{Grau}^{18}$ & PRC pour AC $(n=30)$ & Réussite à la première tentative & $70 \% *$ & $40 \%$ & $<0,036$ \\
\hline Arzola $^{5}$ & Femmes en travail obstétrical $(n=60)$ & Réussite à la première tentative & $92 \%$ & - & - \\
\hline Balki $^{8}$ & Femmes obèses en travail obstétrical $(n=46)$ & Réussite à la première tentative & $76 \%$ & - & - \\
\hline
\end{tabular}

$\mathrm{US}=$ ultrason; $\mathrm{PRC}=$ péridurale-rachidienne combinées; $\mathrm{AC}=$ accouchement par césarienne; $n=$ nombre de patientes. $*$ Le taux de réussite était de $100 \%$ pour les péridurales réalisées à l'aide d'échoguidage en temps réel

Tableau 2 Profondeur estimée par ultrason de l'espace péridural chez les parturientes

\begin{tabular}{|c|c|c|c|c|c|}
\hline Étude & Patientes & Plan de balayage & $\begin{array}{l}\text { Profondeur } \\
\text { de la } \\
\text { ponction }(\mathrm{cm})\end{array}$ & $\begin{array}{l}\text { Coefficient de } \\
\text { corrélation } \\
\left(\mathrm{r}^{2}\right)\end{array}$ & $\begin{array}{l}\text { Précision } \\
\text { selon l'analyse de } \\
\text { Bland-Altman }(\mathrm{cm})\end{array}$ \\
\hline Currie $^{19}$ & $\begin{array}{l}\text { Péridurales pour le travail obstétrical } \\
\quad(n=75)\end{array}$ & sagittal & $4,1 \pm 0,8$ & 0,92 & 0,54 \\
\hline Wallace $^{20}$ & $\begin{array}{l}\text { Péridurales pour le travail obstétrical } \\
\text { chez les obèses }(n=36)\end{array}$ & $\begin{array}{l}\text { médian sagittal / } \\
\text { transverse }\end{array}$ & $5,5 \pm 2,1$ & 0,98 & 0,54 \\
\hline $\mathrm{Grau}^{21}$ & $\begin{array}{l}\text { Péridurales pour le travail obstétrical } \\
\quad(n=100)\end{array}$ & $\begin{array}{l}\text { paramédian sagittal / } \\
\text { transverse }\end{array}$ & $5,3 \pm 0,7$ & 0,79 & 0,68 \\
\hline $\mathrm{Grau}^{16}$ & PRC pour AC $(n=40)$ & $\begin{array}{l}\text { paramédian sagittal / } \\
\text { transverse }\end{array}$ & $5,2 \pm 0,9$ & 0,92 & 0,51 \\
\hline $\mathrm{Grau}^{17}$ & $\begin{array}{l}\text { Péridurales pour le travail obstétrical } \\
\text { dans des cas difficiles }(n=36)\end{array}$ & $\begin{array}{l}\text { paramédian sagittal / } \\
\text { transverse }\end{array}$ & $5,8 \pm 1,1$ & 0,87 & 0,77 \\
\hline $\mathrm{Grau}^{15}$ & $\begin{array}{l}\text { Péridurales pour le travail obstétrical } \\
\quad(n=150)\end{array}$ & $\begin{array}{l}\text { paramédian sagittal / } \\
\text { transverse }\end{array}$ & $5,1 \pm 0,9$ & 0,83 & 0,69 \\
\hline Arzola $^{5}$ & $\begin{array}{l}\text { Péridurales pour le travail obstétrical } \\
\quad(n=60)\end{array}$ & transverse & $4,7 \pm 0,7$ & 0,88 & 0,70 \\
\hline Balki $^{8}$ & $\begin{array}{l}\text { Péridurales pour le travail obstétrical } \\
\text { chez pts obèses }(n=46)\end{array}$ & transverse & $6,6 \pm 1,0$ & 0,85 & 1,00 \\
\hline
\end{tabular}

$\mathrm{PRC}=$ péridurale-rachidienne combinées; $\mathrm{AC}=$ accouchement par césarienne; $n=$ nombre de patientes 
minimise probablement le temps global de l'intervention chez des patientes présentant des repères anatomiques difficiles. L'évaluation de la colonne par échoguidage prend en règle générale 2-3 minutes en moyenne. ${ }^{15-17}$

\section{L'échoguidage comme outil d'enseignement}

L'imagerie par ultrason pourrait potentiellement jouer un rôle dans l'enseignement de l'insertion des péridurales et améliorer les courbes d'apprentissage des personnes en formation en anesthésie. Grau et coll. ont observé un taux de réussite plus élevé ainsi qu'une courbe d'apprentissage plus rapide chez le groupe réalisant des péridurales échoguidées par rapport au groupe ayant appris à insérer les péridurales de façon traditionnelle. ${ }^{22}$ Notre groupe a observé que les novices avaient besoin de beaucoup de pratique afin de perfectionner la technique d'échographie de la colonne lombaire et ce, même après avoir assisté aux cours et aux ateliers. Plus de 20 tentatives sont nécessaires pour maitriser les tâches cruciales requises pour la localisation précise des repères échographiques. Parmi les erreurs fréquemment observées, citons le fait de ne pas trouver l'espace L5-S1, le manque de précision dans le marquage sur la peau, et le glissement involontaire de la sonde vers un segment inférieur lors du marquage du point d'insertion sur la peau. En portant une attention particulière à ces aspects, il est probable que la courbe d'apprentissage de l'échoguidage s'améliorera. ${ }^{23}$ Par conséquent, l'échographie ne devrait pas être réservée uniquement aux cas difficiles d'un point de vue technique, étant donné que cette méthode requiert une expérience avec des cas de routine présentant des repères palpables facilement identifiables avant de pouvoir être utilisée efficacement dans des cas plus difficiles.

\section{Échoguidage en temps réel}

L'échographie en temps réel peut être réalisée comme une technique hors plan en balayant dans une approche longitudinale paramédiane et en insérant l'aiguille péridurale dans la ligne médiane. ${ }^{18}$ Les limites évidentes de cette technique sont une démarcation médiocre des structures individuelles telles que le ligament jaune et la dure-mère ainsi que la présence nécessaire d'un assistant pour réaliser l'échographie. Toutefois, l'utilisation de seringues péridurales munies d'une fonction automatique de perte de résistance pourrait permettre à un opérateur expérimenté de réaliser seul une intervention péridurale échoguidée en temps réel. En fin de compte, si l'on considère l'amélioration de la technologie d'échoguidage et la mise au point d'appareils de guidage de l'aiguille, cette percée pourrait également voir le jour plus tôt que prévu.

\section{Conclusion}

L'échoguidage offre plusieurs avantages potentiels pour la mise en place les blocs rachidiens et périduraux chez les patientes en obstétrique. Avec la disponibilité accrue de cette technologie, une formation adaptée et une prise de conscience accrue de la communauté des anesthésiologistes, l'échoguidage devrait devenir de plus en plus accessible aux parturientes.

\section{Cas clinique}

Une patiente de 29 ans, gravida 2, para 1 (G2P1), arrivée à terme, se présente à l'unité des naissances en début de travail et demande une analgésie péridurale. Son dernier accouchement s'est déroulé par voie basse et sa grossesse actuelle demeure sans incident. Malheureusement, son expérience antérieure avec l'analgésie péridurale a nécessité plusieurs tentatives résultant en une ponction accidentelle de la dure-mère, ce qui a provoqué une céphalée post-ponction dure-mérienne exigeant un colmatage sanguin (blood patch). Évidemment, elle est inquiète à l'idée de répéter l'expérience. Elle mesure $160 \mathrm{~cm}$ et pèse $85 \mathrm{~kg}$, et l'examen de sa colonne lombaire révèle que ses apophyses épineuses ne sont ni visibles ni facilement palpables. Vous décidez d'utiliser l'échoguidage pour identifier les repères anatomiques avant de positionner l'aiguille.

\section{Directives pour compléter le module de développement professionnel continu (DPC)}

1. Lisez cet article et les références en gras.

2. Rendez-vous sur le site Internet du programme d'auto-évaluation du Journal canadien d'anesthésie / Université de Montréal: https://www.cpass2.umontreal. $\mathrm{ca} /$ selfassessmentprogram/; et choisissez le module actuel (L'ultrason pour les péridurales en obstétrique).

3. Répondez aux questions à choix de réponses concernant le cas clinique.

4. Une fois que vous avez saisi toutes vos réponses, vous aurez accès aux explications d'experts pour tous les choix possibles.

5. Les participants peuvent réclamer un maximum de quatre heures de DPC pour un total de huit crédits sous la Section 3 du programme de DPC du Collège royal des médecins et chirurgiens du Canada.

Acknowledgements I would like to acknowledge Dr. Sharon Davies, Associate Professor, Department of Anesthesia, Mount Sinai Hospital, for editing and narrating video script. I am grateful to 
Master Indranil Balki for video production for the module as well as for video and sound editing.

Conflict of interest None declared.

Funding sources None declared.

\section{References}

1. NICE. Ultrasound guided catheterisation of the epidural space. National Institute for Health and Clinical Excellence: January 2008. Available from URL:www.nice.org.uk/nicemedia/pdf/ IPG249Guidance.pdf (accessed September 2, 2010).

2. Sites BD, Brull R, Chan VW, et al. Artifacts and pitfall errors associated with ultrasound-guided regional anesthesia. Part I: understanding the basic principles of ultrasound physics and machine operations. Reg Anesth Pain Med 2007; 32: 412-8.

3. Sites BD, Brull R, Chan VW, et al. Artifacts and pitfall errors associated with ultrasound-guided regional anesthesia. Part II: a pictorial approach to understanding and avoidance. Reg Anesth Pain Med 2007; 32: 419-33.

4. Grau T, Leipold RW, Horter J, Conradi R, Martin EO, Motsch J. Paramedian access to the epidural space: the optimum window for ultrasound imaging. J Clin Anesth 2001; 13: 213-7.

5. Arzola C, Davies S, Rofaeel A, Carvalho JC. Ultrasound using the transverse approach to the lumbar spine provides reliable landmarks for labor epidurals. Anesth Analg 2007; 104: 118892.

6. Carvalho JC. Ultrasound-facilitated epidurals and spinals in obstetrics. Anesthesiol Clin 2008; 26: 145-58.

7. Borges B, Wieczoreck P, Balki M, Carvalho JC. Sonoanatomy of the lumbar spine of pregnant women at term. Reg Anesth Pain Med 2009; 34: 581-5.

8. Balki M, Lee Y, Halpern S, Carvalho JC. Ultrasound imaging of the lumbar spine in the transverse plane: the correlation between estimated and actual depth to the epidural space in obese parturients. Anesth Analg 2009; 108: 1876-81.

9. McLeod A, Roche A, Fennelly M. Case series: Ultrasonography may assist epidural insertion in scoliosis patients. Can $\mathbf{J}$ Anesth 2005; 52: 717-20.
10. Costello JF, Balki M. Cesarean delivery under ultrasoundguided spinal anesthesia in a parturient with poliomyelitis and Harrington instrumentation. Can J Anesth 2008; 55: 606-11.

11. Reynolds $F$. Damage to the conus medullaris following spinal anaesthesia. Anaesthesia 2001; 56: 238-47.

12. Broadbent CR, Maxwell WB, Ferrie R, Wilson DJ, Gawne-Cain $M$, Russell $R$. Ability of anaesthetists to identify a marked lumbar interspace. Anaesthesia 2000; 55: 1122-6.

13. Margarido CB, Mikhael R, Arzola C, Balki M, Carvalho JCA. The intercristal line determined by palpation is not a reliable anatomical landmark for neuraxial anesthesia. Can J Anesth (in press).

14. Watson MJ, Evans $S$, Thorp JM. Could ultrasonography be used by an anaesthetist to identify a specified lumbar interspace before spinal anaesthesia? Br J Anaesth 2003; 90: 509-11.

15. Grau T, Leipold RW, Conradi R, Martin E, Motsch J. Efficacy of ultrasound imaging in obstetric epidural anesthesia. J Clin Anesth 2002; 14: 169-75.

16. Grau T, Leipold RW, Conradi R, Martin E, Motsch J. Ultrasound imaging facilitates localization of the epidural space during combined spinal and epidural anesthesia. Reg Anesth Pain Med 2001; 26: 64-7.

17. Grau T, Leipold RW, Conradi R, Martin E. Ultrasound control for presumed difficult epidural puncture. Acta Anaesthesiol Scand 2001; 45: 766-71.

18. Grau T, Leipold RW, Fatehi S, Martin E, Motsch J. Real-time ultrasonic observation of combined spinal-epidural anaesthesia. Eur J Anaesthesiol 2004; 21: 25-31.

19. Currie JM. Measurement of the depth to the extradural space using ultrasound. Br J Anaesth 1984; 56: 345-7.

20. Wallace DH, Currie JM, Gilstrap LC, Santos R. Indirect sonographic guidance for epidural anesthesia in obese pregnant patients. Reg Anaesth 1992; 17: 233-6.

21. Grau T, Leipold R, Conradi R, Martin E, Motsch J. Ultrasonography and peridural anesthesia. Technical possibilities and limitations of ultrasonic examination of the epidural space. Anaesthesist 2001; 50: 94-101.

22. Grau T, Bartusseck E, Conradi R, Martin E, Motsch J. Ultrasound imaging improves learning curves in obsteric epidural anesthesia: a preliminary study. Can J Anesth 2003; 50: 1047-50.

23. Margarido CB, Arzola C, Balki M, Carvalho JC. Anesthesiologists' learning curves for ultrasound assessment of the lumbar spine. Can J Anesth 2010; 57: 120-6. 